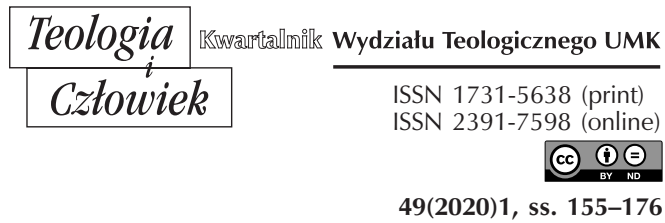

PRZEMYSŁAW SOŁGA

\title{
PRZYCZYNY I OKOLICZNOŚCI ZATARGU KS. STANISŁAWA STOJAŁOWSKIEGO Z POLSKIM KOŚCIOŁEM HIERARCHICZNYM
}

DOI: http://dx.doi.org/10.12775/TiCz.2020.008

\begin{abstract}
Streszczenie. Artykuł ukazuje przyczyny i okoliczności, w jakich działalność społeczno-polityczna ks. Stanisława Stojałowskiego, działacza polskiego ruchu ludowego z przełomu XIX i XX w. spotkała się z negatywnym odzewem ze strony Kościoła katolickiego, zwłaszcza jeśli chodzi o polskich przedstawicieli episkopatu. Przeanalizowano system poglądów ks. Stojałowskiego i zestawiono go z ówczesną katolicką nauką społeczną, a także poddano analizie jego konkretne zachowania i odpowiedzi na słowa krytyki ze strony innych duchownych i przedstawicieli władz świeckich, oraz podjęto próbę wyjaśnienia przyczyn jego postawy.
\end{abstract}

Słowa kluczowe: ks. Stanisław Stojałowski; ruch ludowy; Kościół katolicki; krytyka.

Abstract. Causes and circumstances of the priest Stanisław Stojałowski’s conflict with the Polish hierarchical church. The article considers causes of the negative attitude of the Catholic Church to the priest Stanisław Stojałowski. This text shows how Hierarchy of the Church expressed her disapproval of his socio-political views. The author also paid attention to the biography of the priest Stojałowski, especially for referring with relations with the ecclesiastical authority.

Keywords: priest Stanisław Stojałowski; popular movement; the Catholic Church; criticism. 


\section{FORMACJA KS. STOJAKOWSKIEGO}

Działalność społeczno-polityczna proboszcza z galicyjskiej parafii Kulików, ks. Stanisława Stojałowskiego, znanego polskiego działacza ludowego, organizującego masowe wiece i demonstracje galicyjskich chłopów z przełomu XIX i XX wieku, choć w wielu środowiskach zyskała posłuch, w ostateczności nigdy nie osiągnęła aprobatywnej oceny ze strony hierarchii Kościoła katolickiego. Celem artykułu jest ukazanie zasadniczych determinantów, które zaważyły o tym stanowisku oraz reperkusji, jakie ono za sobą pociągało. Pod uwagę wzięto działalność zarówno Kościoła partykularnego, jak i powszechnego.

Zarówno, życiorys i poglądy księdza Stojałowskiego były bardzo wyrafinowane. Nieraz zmuszony był do ucieczki przed pojmaniem przez policję. Przed sądem przyszło mu stawać aż dwadzieścia dwa razy, co poskutkowało dwuletnim pobytem w więzieniu. W ciągu całego życia pozbawiono go także probostwa i ekskomunikowano ${ }^{1}$. Najwyższa kara kościelna, ekskomunika, została na niego nałożona 5 sierpnia 1896 roku $^{2}$. Duchowny przybył do Rzymu w następnym roku. Tam zdjęto z niego ekskomunikę, a błogosławieństwa udzielił mu sam papież Leon XIII, który przyjął go u siebie na audiencji ${ }^{3}$.

Stanisław Stojałowski początkowo należał do członków Towarzystwa Jezusowego. Bezpośrednio po przyjęciu święceń kapłańskich został wysłany do Belgii na studia, które odbył w latach 1873-1874. W owym czasie zetknął się z tamtejszym ruchem społeczno-chrześcijańskim ${ }^{4}$, co wywarło na niego ogromny wpływ i miało zaważyć na jego dalszej działalności na niwie społecznej. Po powrocie do kraju - być może celowo, by uzyskać większą przestrzeń do działania - opuścił zakon jezuitów i został inkardynowany do diecezji lwowskiej, gdzie zaczął rozwijać swoją działalność społeczną. W 1879 roku założył, wzorując się na poznańskiej działalności Maksymi-

1 A. Zakrzewski, Od Stojałowskiego do Witosa, Warszawa 1988, s. 14.

2 Ł. Szymański, Powstanie i rozwój ruchu ludowego w Galicji na przełomie XIX i XX wieku, „Acta Erasmiana” 2014, t. 6, s. 99.

3 Tamże.

${ }^{4}$ A. Kaleta, Stanowisko władz kościelnych wobec ruchu ludowego w Galicji na przykładzie społecznej i wydawniczej działalności księdza Stanisława Stojałowskiego, „Toruńskie Studia Bibliologiczne”, 2 (2013), s. 122. 
liana Jackowskiego, Towarzystwo Ludowe Oświaty i Pracy. Trzy lata później przekształcił je w Towarzystwo Kółek Rolniczych. Liczba kółek i ich członków wzrastała w zawrotnym tempie - bezpośrednio przed wybuchem pierwszej wojny światowej wynosiła odpowiednio 2081 i 82 000. Funkcję kierowników w tych stowarzyszeniach w Galicji często pełnili księża ${ }^{5}$.

Helena Hempel tak oto opisuje okres pobytu we Lwowie ks. Stojałowskiego, kiedy już był eks-jezuitą:

ks. Stojałowski obok wysokich zdolności i wielostronnej wiedzy, lekceważył nieraz formy i przepisy, również dlatego że posiadając wielce odrębne, osobiste właściwości, nie lubił się krępować w swych działaniach, ilekroć uważał, że pominięcie jakiegoś rozporządzenia nie przyniesie szkody. Stąd to $\mathrm{w}$ owym pięcioletnim okresie 1875-1880 r. za tego rodzaju nieprzestrzeganie obowiązujących formalności, dostawał ze strony duchownej zwierzchności nagany i zagrożenia ${ }^{6}$.

To właśnie niesubordynacja ks. Stojałowskiego, wynikająca w dużym stopniu z jego cech charakterologicznych, miała być jedną z głównych kości niezgody z Kościołem hierarchicznym.

Po przejęciu czasopism „Wieniec” i „Pszczółka” w 1875 roku, skierowanych głownie do chłopów, ksiądz Stojałowski postanowił nadać im poszczególne zadania do realizacji. To pierwsze miało mieć charakter przede wszystkim informacyjny, o zabarwieniu politycznym, z kolei drugie skupiało się na bieżących wydarzeniach dotyczących Kościoła katolickiego oraz podejmowało szeroko pojęte kwestie religijne. W rzeczywistości jednak obydwa czasopisma z biegiem czasu przybrały podobny charakter, zasadniczo różniły się od siebie jedynie tytułem ${ }^{7}$. Istnienie dwóch pism podejmujących tę samą tematykę było podyktowane tym, że w Galicji obowiązywał tzw. „stempel dziennikarski” na tygodniki. Ksiądz Stojałowski ominął ustawę, która go nakładała, wydając dwa czasopisma jako dwutygodniki. Wśród autorów „Wieńca” i „Pszczółki” znaleźli się między innymi posłowie stojałowczycy tacy jak Michał Danielak czy Franciszek

5 Tamże.

${ }^{6}$ B. Filarecka, Zarys stosunku Kościoła do ruchu ludowego w diecezji przemyskiej, „Premislia Christiana” 2001, t. IX, s. 28.

${ }^{7}$ K. Dunin-Wąsowicz, Czasopiśmiennictwo ludowe w Galicji, Wrocław 1952, s. 60. 
Kramarczyk. W 1897 roku oba pisma miały aż 4500 prenumeratorów ${ }^{8}$. Maciej Szarek, przedstawiciel warstwy chłopskiej, w wydanym w 1896 roku „Przyjacielu Ludu” pisał: „a gdy dzięki tym gazetom oraz książkom, które czytałem, przejrzałem na oczy, już nie mówiłem, że jestem cesarski, ale zrozumiałem, że jestem polskim chłopem, a tylko poddanym cesarskim"9.

\section{DZIAŁALNOŚĆ POLITYCZNA}

Kościół katolicki dosyć późno, bo dopiero po ogłoszeniu encykliki Rerum novarum, otworzył się na prasę jako narzędzie służące do ewangelizacji ${ }^{10}$. Wobec przemian i zawirowań zachodzących wówczas w społeczeństwie, ówczesny biskup Krakowa, kardynał Jan Puzyna założył czasopisma: „Prawda”, które było skierowane do chłopów oraz „Postęp”, ukierunkowane na robotników. Idąc w ślad za nim, ze względu na obawy przed opanowaniem ruchu ludowego przez elementy antyklerykalne biskup Tarnowski Leon Wałęga stworzył pismo „Lud Katolicki”"1.

W roku 1893 ks. Stojałowski współtworzył Związek Chłopski, by dwa lata później związać się ze Stronnictwem Ludowym. To mu jednak nie wystarczyło. Zdecydował się na rozwinięcie własnej działalności politycznej, czego wyrazem było utworzone przez niego w roku 1896 Stronnictwo Chrześcijańsko-Ludowe ${ }^{12}$. Na niedługo przed utratą swojego probostwa, w połowie w 1980 roku urządził pielgrzymkę do Ziemi Świętej; zorganizował zbiórkę, z której pieniądze miały być przeznaczone na fundację lampy do Grobu Świętego. Jednakże ostatecznie nie poświęcił ich na ten cel. Oskarżony o oszustwo, wylądował na kilka miesięcy w więzieniu. Polityczna kariera księdza Stojałowskiego zakończyła się na jego przystąpieniu do endecji. Swoje pismo niedługo przed śmiercią zapisał Janowi

8 Tamże, s. 61.

${ }^{9} \mathrm{H}$. Brodowska-Kubicz, Świadomość społeczno-narodowa chłopów. U podstaw ruchu ludowego, w: Chłopi, naród, kultura, t. 2, Działalność polityczna ruchu ludowego, red. S. Dąbrowski, Rzeszów 1996, s. 158.

\footnotetext{
10 A. Kaleta, dz. cyt., s. 124.

11 Tamże, s. 125.

12 A. Zakrzewski, dz. cyt., s. 14.
} 
Zamorskiemu, przywódcy galicyjskich endeków. Ukazywało się ono aż do 1932 roku. Krzysztof Dunin-Wąsowicz tłumaczy ów alians carofilstwem i antysemityzmem księdza, cechami łączącymi go z endekami ${ }^{13}$.

Ruch ludowy był zjawiskiem stosunkowo nowym, choć powstałym na bazie długiej emancypacji chłopów polskich. W Galicji istniały najlepsze możliwości jego rozwoju. Było to podyktowane przede wszystkim większą swobodą życia politycznego niż w innych zaborach, rozwojem życia parlamentarnego oraz oświaty ${ }^{14}$. Nic dziwnego, że hasła lansowane przez ks. Stojałowskiego trafiły na podatny grunt. Wśród ludności chłopskiej cieszył się ogromną popularnością. W ciągu kilkunastu lat niezwykle aktywnej działalności społecznej przyczynił się w Galicji do zwalczania analfabetyzmu wśród chłopów, którzy czasem nawet publikowali w lokalnych pisemkach; organizował im wiece, zakładał kółka rolnicze i pierwsze sklepy chrześcijańskie, tworzył osobne komitety wyborcze dla chłopów, które zaczęły z czasem wybierać własnych posłów ${ }^{15}$. Emancypacja galicyjskich chłopów łączyła się z ich uświadomieniem społecznym, zwiększeniem dobrobytu, a także rozwojem organizacji społeczno-politycznych, kulturalnych i religijnych ${ }^{16}$.

Ksiądz Stojałowski chciał podnieść morale ludu, który w oczach konserwatystów jawił się jako ostoja ciemnoty i bierności politycznej. Podejmował często organizację wieców, które w kręgach konserwatywnych wywoływały bardzo negatywne konotacje, jako że kojarzyły się z buntem, stanowiącym preludium do rewolucji. Bunty chłopów byłe skrajnie negatywnie odbierane $\mathrm{w}$ tych środowiskach, gdyż wciąż żywe były w świadomości właścicieli ziemskich zdarzenia związane z rabacją galicyjską z 1846 roku $^{17}$. W podobnym duchu co do działalności ks. Stojałowskiego odnosiły

13 Tamże, s. 63-64.

${ }_{14}$ D. Olszewski, Kościół katolicki a ruch ludowy na ziemiach polskich na przełomie XIX i XX wieku, w: Wieś polska wobec wyzwań, przełomów i zagrożeń (XIX i XX wiek), red. M. Przeniosło, S. Wiech, Kielce 2005, s. 9.

15 J. Zamorski, Ks. Stanisław Stojałowski, Bielsko 1931, s. 37.

16 P. Jakubiec, „Dwie dusze” - czyli ewolucja tożsamości społecznej i narodowej ludności chłopskiej Galicji w drugiej połowie XIX i na początku XX wieku, „Zeszyty Naukowe Uniwersytetu Jagiellońskiego. Prace Historyczne” 144 (2017), z. 2, s. 418.

${ }_{17} \mathrm{~K}$. Turowski, Historia ruchu chrześcijańsko-demokratycznego w Polsce, cz. 1, Warszawa 1989, s. 34. 
się władze administracyjno-rządowe i namiestnikowskie, zdaniem których jego aktywność polityczna burzyła dotychczasowy porządek społeczny ${ }^{18}$. Według niektórych badaczy na tym także zasadzała się istota konfliktu pomiędzy nim a władzami kościelnymi w Galicji; nie miał on bynajmniej charakteru wyłącznie personalnego, ale wiązał się ze zjawiskiem emancypacji polskiego ludu ${ }^{19}, \mathrm{w}$ czym poniekąd słusznie dopatrywano się działalności godzącej w obowiązujący porządek społeczny.

Emancypacja chłopów łączyła się też czasem z hasłami antyklerykalnymi. Chłopski antyklerykalizm, którego zalążki podówczas można było zauważyć, zdaniem Andrzeja Zakrzewskiego nie był jednak wymierzony w wiarę i Kościół - te wartości bowiem pozostały niezachwiane. Włościanie sprzeciwiali się jednak „dotychczasowemu patronatowi księży nad ich życiem społecznym i politycznym. Im bliższe były związki wiejskiego proboszcza z miejscowym dworem, tym radykalniejsze formy przybierał chłopski protest" ${ }^{20}$. Wśród tej warstwy przywiązanie do religii było czymś naturalnym, elementem - można by rzec - odwiecznej tradycji ${ }^{21}$.

Chłopów i warstwę robotniczą w Galicji łączyła niechęć do pozostałości postfeudalnej, jaką była warstwa obszarnicza nazywana „szlachetczyzną"22. Kolejnym wspólnym wrogiem był kler, ze szczególnym uwzględnieniem biskupów. Kościół chętnie udzielał się w sferze polityki, wyrażając własne zdanie lub udzielając komentarzy na temat zaistniałej sytuacji społeczno-politycznej ${ }^{23}$. Wiele kontrowersji wśród Galicjan wywołało zalecenie tarnowskiego bp. Wałęgi, by księża w podlegającej mu diecezji nie udzielali rozgrzeszenia wszystkim nupturientom czytającym „Przyjaciela Ludu”, oraz odchylającego się w stronę socjalizmu czasopi-

18 Tamże.

19 A. P. Bieś SJ, Jan Badeni SJ (1858-1899). U początków ruchu społecznego katolików w Galicji, Kraków 2012, s. 179.

20 A. Zakrzewski, dz. cyt., s. 14.

${ }^{21}$ K. Dunin-Wąsowicz, Ludowcy i Socjaliści w Galicji, w: Chłopi, naród, kultura, t. 1, Myśl polityczna ruchu ludowego, red. J. Jachymek, K.Z. Sowa, M. Śliwa, Rzeszów 1996., s. 203.

22 Tamże, s. 201.

23 Tamże, s. 203. 
sma „Prawo Ludu”24. Biskup Wałęga pozostał jednak nieugięty, a protesty diecezjan nie przyniosły rezultatu.

Taka decyzja biskupa nie powinna budzić zaskoczenia. Społeczeństwo chłopskie można bowiem przyrównać do ludzi w młodym wieku, o słabo wykształconej wolitywnej sferze charakteru i podatnych na manipulację. Propaganda siana $\mathrm{w}$ tych periodykach mogła bezsprzecznie wpływać modelująco na kształtowanie się poglądów warstwy chłopskiej, która nie była przecież rozwinięta tak dobrze jak wykształceni ludzie. Koniec XIX i początek XX wieku wiązały się ze zmianami w mentalności społeczeństwa, także jeśli chodzi o kwestie religijne. W szczególny sposób zjawisko to unaoczniło się w galicyjskiej społeczności chłopskiej. Miało to bezpośredni związek z równoległym, jeśli chodzi o kwestie społeczne, rozwojem ruchu ludowego i działalności duszpasterskiej Kościoła katolickiego ${ }^{25}$. Duchowieństwo na tym obszarze, zwłaszcza hierarchowie kościelni, tacy jak arcybiskup lwowski Józef Bilczewski czy biskup przemyski Józef Pelczar, dokładali starań, aby w ich diecezjach rozwijała się katolicka nauka społeczna zgodna $\mathrm{z}$ wytycznymi zarysowanymi przez papieża Leona XIII w encyklice Rerum novarum. Do tej samej działalności zachęcali znajdujących się pod ich jurysdykcją księży, co znalazło odzwierciedlenie także w galicyjskiej prasie katolickiej ${ }^{26}$. Austriacki zaborca tymczasem wykorzystywał chłopów do walki z polską szlachtą ${ }^{27}$.

Napięta sytuacja ks. Stojałowskiego wynikała także z jego problemów finansowych i nietypowych sposobów ich rozwiązywania. Narobił on sobie długów z rzędu kilkunastu tysięcy guldenów, licząc na „plebańskie dochody”, tymczasem namiestnik Potocki w 1883 roku zają cały dochód z ziemi plebańskiej na rzecz skarbu państwa, celem wypłaty opłat kościelnych należnych z racji patentu cesarza Józefa II. Ksiądz z Kulikowa znalazł się w długach i bez grosza. Codzienne czasopisma, nawet te o specjalności „humorystycznej” we Lwowie i w Krakowie poczęły sobie

24 Tamże.

25 A. Kaleta, Stanowisko władz kościelnych wobec ruchu ludowego w Galicji na przykładzie społecznej i wydawniczej działalności księdza Stanisława Stojałowskiego, „Toruńskie Studia Bibliologiczne” 2 (2013), s. 121.

26 Tamże, s. 122.

27 Ł. Szymański, dz. cyt. s. 97. 
z niego drwić. Niedługo potem urządzał w swojej parafii misje, na które zaprosił oo. redemptorystów. Ci z kolei, za sprawą posłyszanych poczynań ks. Stojałowskiego, przestrzegali w konfesjonałach parafian przed ich własnym proboszczem i nie przyjęli od niego obiadu ${ }^{28}$.

Po pielgrzymce do Ziemi Świętej w 1887 roku rządzący konserwatyści oskarżyli go o oszukiwanie chłopów, od których pobierał pożyczki. Ks. Stojałowski usłyszał zarzuty prokuratorskie i rozpoczął się jego proces sądowy, na którym bronił się sam. W czasie jednego z przemówień miał powiedzieć: „z przyjemnością stwierdzam, że w szeregu tych, co mnie oskarżają, nie ma ani jednego chłopa, to jest właśnie tych, których rzekomo miałem pokrzywdzić. Ci co na chłopa z góry patrzą zostali nagle jego opiekunami"29. Niczego mu nie udowodniono poza zadłużeniem, a ze względu na niewypłacalność długów został skazany na 3 miesiące więzienia i pozbawiono prawa wybieralności na posła ${ }^{30}$.

Ksiądz Stanisław Stojałowski jako pierwszy rozpoczął działalność polityczną na gruncie wiejskim ${ }^{31}$. W 1896 roku wspominał: „postanowiłem zostać agitatorem - i bez układania obszerniejszych programów, których w owym czasie i tak nie byłby lud zrozumiał, ująłem program i hasła ruchu ludowego w dwóch słowach: gazetki polityczne i wiece. To były środki a celem, który mi przyświecał, było unarodowienie chłopa i pozyskanie dla ojczyzny nowych synów i obrońców. Tak bowiem pojmowałem słowa Zygmunta Krasickiego: „z szlachtą polską polski lud"32. Uważał on, że dla Polski, by mogła się odrodzić, niezbędny jest upadek dwóch zaborców - Rosji i Prus, a jednocześnie trzeba działać od wewnątrz. Pisał: „niepodległość, a raczej restauracja niepodległości Polski, w części zależy od nas samych, a w części od rozwoju wypadków narodowo-politycznych w Europie ${ }^{33}$. Z kolei w 1895 roku odnotował: „za pierwsze przykazanie miłości ojczyzny poczytujemy roztropność i wyleczenie się z polityki uczuć, a za pierwszy cel rozumnej polityki dążenie do

28 J. Zamorski, dz. cyt., s. 43.

29 Tamże, s. 38.

30 Tamże.

31 A. Zakrzewski, dz. cyt., s. 15.

32 Tamże, s. 13.

${ }^{33}$ Cyt. za: A. Zakrzewski, dz. cyt., s. 15. 
uświadomienia mas ludowych i zjednoczenia narodu, jako nieodzownego warunku dalszego rozwoju dążeń narodowych" ${ }^{34}$.

Postulował rozszerzenie praw obywatelskich, zwłaszcza demokratyzację prawa wyborczego, utworzenia samorządu krajów, powiatów i gmin „nieskrępowanego przez urzędników”. Wskazywał, że lud powinien mieć prawo do wyboru na wszystkie urzędy publiczne. „Żądał poszanowania wolności osobistej i zniesienia wszelkich praw policyjno-sądowych, które wolność obywatelską zdają bezkarnie na łaskę i niełaskę urzędników państwowych”35. Stwierdzał także: „chcę zbudować chłopa, ale tak zbudować, aby poczuł że jest Polakiem" ${ }^{36}$. Nie zależało mu jednak na zantagonizowaniu chłopstwa i szlachty; chodziło raczej o poprawę sytuacji tej pierwszej warstwy, o czym świadczą słowa: „do pracy tej zapraszam szlachtę, która nie powinna bać się chłopów” i „niech szlachta idzie razem, aby chłopi nie szli bez niej" ${ }^{37}$. Być może zdawał sobie sprawę, jak niewielkie preliminaria stoją w obrębie włościan i że jeśli chçą oni coś ugrać na niwie politycznej, niezbędna będzie pomoc bardziej uświadomionego stanu, gdyż we własnym zakresie, niewiele mogą zdziałać. Reformy musiały iść przecież odgórnie, tam, gdzie zapadały poszczególne decyzje w gremiach, których przytłaczającą większość stanowili przedstawiciele ziemiaństwa, nawet jeśli nie liczebnie, to znaczeniem głosów. Nie dziwi zatem fakt, że ks. Stojałowski zabiegał o posłuch wśród przedstawicieli szlachty. $\mathrm{Na}$ niewiele jednak te apele się zdały, gdyż do osiągnięcia ostatecznego zwycięstwa potrzebował w zasadzie bardziej wsparcia duchowieństwa, a to z kolei było nie po myśli „postępowego” eksjezuity.

Potępiając zarówno liberalizm, jak i socjalizm, a także drobny przemysł i handel, ks. Stojałowski dążył do stworzenia sojuszu drobnomieszczaństwa i chłopstwa ${ }^{38}$. Odmówił socjalistom kierowania rewolucyjnym, skrajnym ruchem ludowym ${ }^{39}$, nie poparł też, wbrew spodziewaniem galicyjskich biskupów, po zniesieniu ciążącej na nim klątwy krakowskich

\footnotetext{
34 Cyt. za: tamże.

35 Cyt. za: tamże.

36 Cyt. za: tamże.

37 Cyt. za: tamże.

38 K. Dunin-Wąsowicz, dz. cyt., s. 62.

39 J. Zamorski, dz. cyt., s. 50.
} 
Stańczyków ${ }^{40}$. Stojałowski krytykował m.in. politykę historyczną tych ostatnich (tzw. krakowską szkołę historyczną) co do kwestii rozbiorów polski i ich bierną postawę wobec spraw Polski w parlamencie ${ }^{41}$. Stańczycy pod koniec lat osiemdziesiątych poczęli korumpować chłopów i wchodzić z nimi w koneksje. Była to odgórnie wykoncypowana taktyka, mająca za zadanie godzić w interesy chłopów: „konserwatyści nie mogli zdławić żywiołowego ruchu ludowego, więc go rozbili, osłabili i upodlili”"42.

Stojałowski był monarchistą i twierdził, że Galicja wszystko co dobre zawdzięcza Habsburgom, którzy nie byli winni wydarzeń z 1846 roku ani złej sytuacji materialnej mieszkańców, gdyż odpowiedzialność za nią spoczywa na nich samych. Jest ona dzięki nim najszczęśliwszym krajem ze wszystkich zaborów, a rzeczona dynastia jest jedyną rodziną panującą w Europie, która zasługuje na zaufanie polskiego narodu. Była to postawa ewidentnie sprzeczna $\mathrm{z}$ jego sądami głoszonymi na łamach wydawanej przez niego prasy. Zdaniem Franciszka Kąckiego rzutuje to negatywnie na jego przekonania i wynika z sytuacji, w której znalazł się galicyjski proboszcz, gdzie tylko rząd centralny mógł go ocalić w obliczu bezwzględnego powstępowania sądów galicyjskich ${ }^{43}$.

Ksiądz Stojałowski krytykował polskie władze, przede wszystkim hr. Badeniego. Propagował chłopskie powiedzenie „broń Boże, aby polskie rządy nadeszły”; „niech się brutalstwem wrogowie raczej plamią” - pisał w swoich wspomnieniach ${ }^{44}$. Ten częściowy antypolonizm wymierzony w polskie władze był krajowym politykom o tyle nie w smak, że podbudzał nieuświadomioną politycznie warstwę chłopską - w której nie wykrystalizowało się jeszcze dostatecznie poczucie przynależności narodowej - przeciwko Polski i polskości.

Dla ruchu ludowego istotna była działalność społeczna kleru, który mógł na niego wpływać aktywizująco. Kościół podejmował różnego rodzaju inicjatywy zmierzające do wywarcia wpływu na stronnictwa chłopskie. Jednocześnie stosunek tych ugrupowań do spraw religijnych musiał

40 Tamże, s. 63.

${ }^{41}$ Tamże, s. 79.

${ }^{42}$ Tamże, s. 61.

${ }^{43}$ F. Kącki, Ks. Stanisław Stojałowski i jego działalność społeczno-polityczna, Lwów 1937, s. 131.

${ }^{44}$ J. Zamorski, dz. cyt., s. 42. 
kształtować autorytet, jakim cieszył się kapłan w środowiskach wiejskich, oraz tradycyjne przywiązanie chłopa do religii, w tym przypadku katolickiej ${ }^{45}$. Ruch ludowy piętnował nadmierny klerykalizm w społeczeństwie. W programie PSL z 1908 roku napisano:

Nigdy nie było zamiarem Polskiego Stronnictwa Ludowego, aby na szkodę narażać to wielkie dobro ludu, jakim jest religia katolicka i prawidłowy stosunek do duchowieństwa. [...] Jesteśmy przeciwnikami wszechwładzy duchowieństwa w narodzie, uważamy za szkodliwe dla Kościoła i duchowieństwa jego nadmierne mieszanie się do spraw i walk politycznych, ale chcemy oddać duchowieństwu, co mu się słusznie należy, aby także ludowi było oddane, co ludowego ${ }^{46}$.

Widać tutaj ewidentną aluzję do ewangelicznych słów Chrystusa oraz chęć oddzielenia Kościoła od państwa, która kłóciła się z ówczesną doktryną katolicką. Ksiądz Stojałowski nie miał zamiaru za pomocą swych pism niszczyć zastanego porządku społecznego, wypowiadał się w sposób idealistyczny na temat historii Polski szlacheckiej oraz wyrażał już wspomnianą lojalność względem monarchii habsburskiej ${ }^{47}$. Przywiązywał także wagę do nastrajania patriotycznego chłopów. W tym celu zorganizował w 1883 roku pielgrzymkę włościan do Krakowa dla upamiętnienia 200. rocznicy odsieczy wiedeńskiej ${ }^{48}$.

\section{ODPOWIEDŹ KOŚCIOŁA}

Działalność ks. Stojałowskiego niemal od samego początku spotykała się jednak z negatywnym, choć nie zawsze jednoznacznie, odzewem ze strony Kościoła. Biskup tarnowski Wałęga apelował do wiernych w 1903 roku, protestując przeciwko ruchowi ludowemu:

${ }_{45}$ T. Chrobak, Etos chłopski w programach stronnictw ludowych, Rzeszów 1992, s. 97.

${ }^{46}$ Cyt. za: tamże, s. 99.

47 K. Dunin-Wąsowicz, dz. cyt., s. 62.

${ }^{48}$ Ł. Szymański, dz. cyt., s. 98. 
Złe przybiera takie rozmiary, że dłużej tolerować nam go nie wolno; musimy przeciwko niemu wystąpić wszyscy ze zgodną stanowczością, jeżeli nie chcemy doczekać się bardzo smutnych czasów, w których już nie jednostki, ale całe parafie będziemy mieli przeciw sobie ${ }^{49}$.

Arcybiskup lwowski Seweryn Morawski tak oto wyraził się na temat księdza Stojałowskiego w 1894 roku:

Pisma periodyczne drukiem ogłaszane „Wieniec Polski”, „Pszczółkę” i „Dzwon” jako wielce zgubne, szkodliwe i niebezpieczne nie tylko potępiliśmy, lecz zarazem zakażaliśmy pod grozą kar kościelnych wiernym pisma te czytać, wspierać, prenumerować i rozszerzaćs ${ }^{50}$.

Jan Badeni, redaktor jezuickiego „Przeglądu Powszechnego” chwalił co prawda ks. Stojałowskiego za tworzenie takich instytucji, jak kółka rolnicze, Towarzystwo Ochrony Ziemi ZSCh, jednak nie miał wątpliwości co do tego, że wszystkie te dzieła wymknęły się spod kontroli jego twórcy. Ponadto imputował mu podburzanie duchowieństwa przeciwko biskupom, co mogło się jego zdaniem zakończyć schizmą i utworzeniem Kościoła narodowego; zarzucał mu także niesubordynację, kwestionowanie autorytetu nauczycielskiego oraz instrumentalne traktowanie nauczania papieskiego wyrażonego w encyklikach. Poza przedstawionymi powyżej zarzutami natury eklezjalnej znalazły się także i te dotyczące działalności społecznej, gdzie wyrzucał mu niechęć i nieufność, a nawet nienawiść do osób zamożniejszych (egalitaryzm), czego pochodną było podburzanie ludu do przewrotów oraz nieprzyjaźń zachodząca pomiędzy stanami społecznymi. Krytykował również jego wykorzystywanie ruchu do zaspokajania własnej ambicji: „mniemał, że potrafi ukształcić sobie z chłopów powolne narzędzie, i z góry groził nim wszystkim nie zgadzającym się z jego planami i drogami" ${ }^{51}$.

Namiestnik Kazimierz Badeni był inicjatorem w sumie kilkunastu aresztowań ks. Stojałowskiego, zlicytowania jego majątku oraz wydawania

${ }^{49}$ Cyt. za: D. Olszewski, Kościół katolicki a ruch ludowy na ziemiach polskich na przełomie XIX i XX wieku, s. 12.

${ }^{50}$ Cyt. za: tamże, s. 10.

${ }^{51}$ A. P. Bieś SJ, dz. cyt., s. 176-177. 
listów gończych. Ks. Stojałowski odczuwał z tych powodów niechęć do całej rodziny Badenich. Namiestnika nazywał bez żadnych ogródek „bestią nie tylko wściekłą, ale i bezwstydną” czy też „łotrem, bandytą i zbirem"52. Gdy Jan Badeni zajął wszystkie dochody z probostwa w 1888 roku, Stojałowski odwołał się do konsystorza, który odpowiedział stanowczo: "przestań wydawać gazety i wiecować, a będziesz miał spokój" ${ }^{3}$.

Napięcia pomiędzy duchowieństwem a chłopami w omawianej kwestii miały różnorakie podłoże. Episkopat katolicki dążył do podporządkowania sobie stronnictwa chłopskiego, które to z kolei nosiło się z zamiarem uzyskania pełnej niezależności, co tylko podsycało eskalację skrajnych postaw wśród chłopów ${ }^{54}$. Jednocześnie narastała krytyka z ambon. Chłopom zaangażowanym $\mathrm{w}$ ten ruch niekiedy zabraniano wstępu do Kościoła i nie udzielano sakramentu spowiedzi ${ }^{55}$.

W grudniu 1877 roku konsystorz lwowski obłożył ks. Stojałowskiego naganą, stwierdzając, że to, co robi, sprzeciwia się „porządkowi i karności”. W 1888 roku konsystorz zarzucił mu „brak uległości”. Jak zauważał K. Kącki: „konsystorz wcale nie liczył się z tym, że dotyka suspensą znanego w całej Galicji pisarza i działacza, mającego za sobą kilkadziesiąt rozpraw religijnych i społecznych, setki artykułów i przemówień, a co najważniejsze, posiadającego sympatie wsi”. I jak przyznał ten sam autor „samego Stojałowskiego, jako wierzącego, suspensa wyprowadziła $\mathrm{z}$ równowagi psychicznej i była dla niego niepowetowanym ciosem moralnym"56. Mimo wszystko proboszcz z Kulikowa suspensy nie uznał i odprawiał msze święte na masową skalę, a gdy proboszczowie nie odmawiali mu celebracji we własnych kościołach, odprawiał je w chłopskich chałupach i stodołach ${ }^{57}$. Nie zboczył też z obranego przez siebie kursu. W tej sytuacji w 1888 roku obłożono go po raz pierwszy karą suspensy. Rozpoczął się przeciwko niemu proces kanoniczny, którego finał stanowiła kolejna suspensa, nałożona tym razem w 1894 roku ${ }^{58}$.

\footnotetext{
52 Tamże, s. 180-181.

53 J. Zamorski, dz. cyt., s. 35.

${ }^{54}$ A. Kaleta, dz. cyt., s. 132.

55 Tamże.

${ }^{56}$ F. Kącki, dz. cyt., s. 127.

57 J. Zamorski, dz. cyt., s. 35.

${ }^{58}$ A. Zakrzewski, dz. cyt., s. 14.
} 
Biskup Solecki 30 maja 1883 roku wydał „Kurendę”, w której poparł działalność ks. Stojałowskiego zarówno w zakresie oświaty jak i rozwoju gospodarczego zacofanego w Galicji rolnictwa; pośrednio zrobił to także dlatego, że działalność kółek rolniczych przyczyniała się do załamania w tym regionie hegemonii Żydów w handlu miejskim i wiejskim ${ }^{59}$. Ten entuzjazm nie udzielał się jednak innym biskupom. W grudniu 1893 ukazał się list pasterski biskupów diecezji: tarnowskiej - Łobosa, przemyskiej - Soleckiego, do których dołączono także arcybiskupa lwowskiego - Morawskiego. Miał on na celu odżegnać wiernych od lektury pism wydawanych przez ludowców, takich jak „Wieniec”, „Pszczółka”, „Przyjaciel Ludu”, a także redagowanego przez socjaldemokratów czasopisma „Naprzód”60. Pasterze Kościoła zabraniali zarówno czytania zawartych w nich informacji, jak i ich rozprzestrzeniania ${ }^{61}$. Ksiądz Stojałowski starał się przekonać biskupów o swoim posłuszeństwie, co na krótki okres poprawiło jego sytuację. Jednakże w 1896 roku została nań nałożona nowa klątwa, pod którą tym razem podpisali się wszyscy biskupi diecezji w obrębie Galicji. Konstatowano m.in. że Stojałowski „psuje wiarę”, „podburza przeciw zwierzchności świeckiej i kościelnej”, jest „nieposłuszny rozkazom biskupów i kongregacji rzymskiej”62. Działający na terenie Galicji Wincenty Witos pisał:

Klątwa na ks. Stojałowskiego „Za nieposłuszeństwo władzy duchownej” zrobiła w powiecie niesłychane wrażenie. Podczas odczytywania jej w kościele rozlegały się głośne płacze i przytłumione szlochania. Tak klątwa, jak i ceremoniał zastosowany przy odczytywaniu robiły prawdziwą grozę i przestrach, ale równocześnie też wzbudzały nie tylko zaciekawienie, ale cichy zacięty bunt, żal do władzy i sympatię dla wyklinanego. Ks. Stojałowski stawał się dla chłopów jakąś wielką legendarną postacią ${ }^{63}$.

Stojałowski, podbudowany poparciem ze strony ludu, a także niektórych księży, postanowił odwołać się do Stolicy Apostolskiej. W 1897

59 B. Filarecka, dz. cyt., s. 31-32.

${ }^{60}$ K. Dunin-Wąsowicz, Dzieje Stronnictwa Ludowego w Galicji, Warszawa 1956, s. 97.

${ }^{61}$ Ł. Szymański, dz. cyt., s. 99.

${ }^{62}$ A. Zakrzewski, dz. cyt., s. 14.

${ }^{63}$ Cyt. za: D. Olszewski, dz. cyt., s. 11. 
roku przybył do Watykanu. Ciążąca na nim klątwa została zdjęta. Po powrocie do kraju nie angażował się już jednak w rozwój ruchu ludowego ${ }^{64}$. Anna Potocka z Rymanowa przyczyniła się do tego, że ks. Stojałowski uznał ciążącą na nim klątwę, kwestionując wcześniej jej ważność, po czym udał się do Rzymu, gdzie ją z niego zdjęto po tym jak odwołał swoje wypowiedzi w których kontestował uprawnienia władz kościelnych co do nauczania i napominania wiernych. Wynika to jasno z jej listów i wspomnieńn ${ }^{65}$.

Zaraz po zniesieniu klątwy do Rzymu wybrał się biskup Jan Puzyna i pod jego wpływem odwołano uczestnictwo ks. Stojałowskiego w papieskiej mszy świętej. 25 września krakowski biskup spotkał się tam z ks. Stojałowskim. Ten ostatni tak skwitował tę rozmowę w swoich wspomnieniach: „poszedłem tu wczoraj do Puzyny i próbowałem się z nim rozmówić na rozum i po chrześcijańsku - ale jest tak ograniczony, że sprawdza się na nim przysłowie: lepiej z mądrym zgubić niż z głupim znaleźć" ${ }^{66}$.

Stojałowski zajmował probostwo w Kulikowie, gdzie 24 maja 1888 roku ówczesny krakowski biskup sufragan Jan Puzyna złożył wizytację. Na księdza nałożono suspensę i pozbawiono go probostwa ${ }^{67}$. Istotne jest to, że zanim doszło do wizyty ks. Stojałowski przesłał krakowskiemu sufraganowi list z własnymi oczekiwaniami co do skutków wizyty. Domagał się w nim, aby biskup przyjechał dzień wcześniej i załatwił sprawy związane z jego parafią, które są zaniedbywane od ośmiu lat; zażądał uregulowania spraw finansowych jego parafii przez Ordynariat, który nałożył w 1883 roku kondukt na jego dochody. Żądał też rozpatrzenia zalegających od kilku lat w konsystorzu kierowanych pod jego adresem doniesień, gdyż ich nierozpatrzenie przyczyni się do zwiększania jego wydatków. Odnotował tez na końcu listu gromkim tonem, że na wypadek nieuwzględnienia jego prośby podniesione w liście sprawy przekaże właściwemu sądowi. Bp Puzyna ewidentnie zbulwersował się postawą Stojałowskiego. Bezpośrednio przed wizytacją odbył konfederację ze starostą Geringiem, na której zasięgnął jego opinii co do postawy Stojałowskiego, po czym oznajmił mu, ze

\footnotetext{
${ }^{64}$ A. Zakrzewski, dz. cyt., s. 14-15.

65 A. P. Bieś SJ, dz. cyt., s. 182.

${ }^{66}$ J. Zamorski, dz. cyt., s. 63.

67 Ł. Szymański, dz. cyt., s. 99.
} 
wizytacja kanoniczna w parafii tego ostatniego zakończy się suspensą, co faktycznie nastąpiło. W trakcie wizytacji Puzyna wznosił dwa razy toast za proboszcza - co można odczytać jako wyraz pewnego wyrachowania jednak całkowicie unikał z nim jakiejkolwiek rozmowy. Akt suspensy wręczył ks. Stojałowskiemu na godzinę przed odjazdem a wcześniej, pod jego nieobecność, obwieścił ją zgromadzonym tłumom oczekującym na błogosławieństwo. Zdaniem Franciszka Kąckiego główną przyczyną suspensy były inwektywy kierowane przez Stojałowskiego pod adresem krakowskiego biskupa, którego obarczał winą, jeśli chodzi o nakładanie konduktów na jego dochody, oraz jawne lekceważenie upomnień, które mu dawał w trakcie kanonicznej wizytacji ${ }^{68}$. Biskup Puzyna zarzucał mu m.in. zniesławienie autorytetu biskupa w wydanej w 1888 roku „Odprawie potwarców”, niespłacanie bezmyślnie zaciąganych długów oraz lekceważenie licznych napomnień ze strony władz kościelnych ${ }^{69}$.

Arcybiskup Morawski nie stawił się parafii Kulikowskiej, pomimo próśb ks. Stojałowskiego. Zamiast tego na wizytację kanoniczną wysłał sufragana bpa Jana Puzynę, który nie przeprowadzając rozmowy z oskarżonym, 24 maja 1988 roku wydała dekret, niezgodny z prawem kanonicznym, gdyż wydanym bez uprzedniego procesu przed sądem duchownym, na mocy którego ks. Stojałowski został zawieszony w funkcji proboszcza ${ }^{70}$.

$\mathrm{Na}$ początku listopada sąd skazał ks. Stojałowskiego na 4 tygodnie aresztu, choć przebywał w nim już od 6 miesięcy. Wszelkie apele i listy podejmowane do arcybiskupa lwowskiego pozostały bez odpowiedzi ${ }^{71}$. Bez odzewu pozostawały również listy parafian z Kulikowa do biskupa lwowskiego, w których brano w obronę ks. Stojałowskiego. W numerze 12 czasopisma „Pszczółka” z 1889 roku ukazał się list tychże parafian, w którym podnoszono wielkie zasługi duszpasterskie i organizacyjne ks. Stojałowskiego oraz zarzucano bpowi Puzynie, że nie chciał z nimi

${ }^{68}$ F. Kącki, dz. cyt., s. $125-127$.

69 B. Filarecka, dz. cyt. ,s. 33.

${ }^{70}$ Biografista duszpasterza polskiego ruchu ludowego K. Kącki przyznaje, że motywy wydania dekretu były bardzo słabe i pozbawione podstaw. Przede wszystkim był sprzeczny z prawem kanonicznym gdyż nie uprzedziło go żadne oficjalne napomnienie ani sąd duchowny; stąd był raczej aktem politycznym, który nie miał większego znaczenia nawet dla duchowieństwa. Zob. K. Kącki, dz. cyt., s. 127.

${ }^{71}$ K. Turowski, dz. cyt., s. 36-37. 
rozmawiać, a jedynie z tymi ludźmi, co do których nie można mieć zaufania $^{72}$.

Biskup Jan Puzyna po tych zajściach w dalszym ciągu angażował się w działalność wymierzoną przeciwko Stojałowskiemu. W jednym z listów do biskupa Bilczewskiego ks. Stojałowski pisał:

Jaki zachodzi stosunek między mną i Jego Ekscelencją Kardynałem Puzyną, to się przedarło do publicznej wiadomości, ale mało kto wie, że Jaśnie $\mathrm{X}$. Biskup Wałęsa był $\mathrm{w}$ tej sprawie, tj. $\mathrm{w}$ wyrzuceniu mnie $\mathrm{z}$ probostwa, wraz z Jaśnie X. Arcybiskupem Weberem prawą ręką Jaśnie X. Puzyny. Więc rzecz tak stoi: Jego Ekscelencja Kardynał Puzyna, X. Arcybiskup Weber i X. Biskup Wałęga - muszą stać na stanowisku, że „Stojałowski to najgorszy człowiek" i z nim nie można gadać ani mu wierzyć, bo z tej zasady wychodzili, gdy nie pytając mnie ani nie dając możności obrony pozbawiali mnie probostwa. Jaśnie X. Biskup Wałęga był przeznaczony na „Kuratora” dla mnie - ale ze mną nigdy słowa nie mówił w toku procesu, choć do niego się zgłaszałem ${ }^{73}$.

Edward Komar, spowiednik biskupa Puzyny, odnotował w swoich wspomnieniach:

[...] niechrześcijańska, niekatolicka akcja ks. Stojałowskiego utorowała drogę niektórym dzisiejszym stronnictwom, które nielitościwie wyzyskują ciemny i biedny lud do swych partyjnych lub osobistych celów, lecz - co pewne - osłabiają w nim wiarę, podkopują zaufanie do władzy duchownej, zaszczepiają nienawiść klasową, podsycają niższe instynkta. To wszystko dzieje się pod pozorem dobra ludu, jego uświadomienia i polepszenia jego obecnej doli. Do takiej pracy społecznej i politycznej ośmielił wszystkich i nauczył jej ks. Stanisław Stojałowski. Prawdziwy mistrz w szerzeniu rewolucji w umysłach i sercach ${ }^{74}$.

W kolejnym z listów z 22 stycznia 1901 roku do biskupa Józefa Bilczewskiego ksiądz Stojałowski zawarł następujące słowa: „co do niezgodności z nauką Kościoła, to już przecie res iudicata. Dwa razy byłem

72 B. Filarecka, dz. cyt., s. 34.

${ }^{73}$ J. Wołczański, Listy ks. Stanisława Stojałowskiego do arcybiskupa Józefa Bilczewskiego z lat 1901-1902, „Nasza Przeszłość” 1998, t. 90, s. 401.

74 E. Komar, Kardynał Puzyna. Moje wspomnienia, Kraków 1912, s. 107-108. 
w Rzymie i dwa razy święte oficjum nic contra Fidem nie znalazło. Gdzież jeszcze mam pójść po sąd w tej sprawie? Ale ja tego sądu nie unikam, owszem, ja go szukam"75. Proboszcz parafii w Kulikowie nie mógł jednak liczyć na poparcie lwowskiego arcybiskupa. 24 października 1911 roku, już po śmierci księdza Stojałowskiego, Bilczewski zanotował:

Umarł X Stojałowski. Poseł Zamorski przysłał mi telegram zapraszający na pogrzeb. Szczyt głupoty lub bezczelności. I ogłosił jeszcze w dziennikach, że zaprosił biskupów. Daj Panie Boże zmarłemu Niebo... ale torował nawet schizmie drogę. Starałem się w moim domu osobiście otworzyć oczy na błędy zawarte w szczotkowym odbiciu jego Kalenda$r z a$; tłumaczył, że tych błędów nie widzi, upierał się [...] Wykształcenie teologiczne miał dostateczne; nie mogłem jego uporu tłumaczyć sobie inaczej, jak złą wolą ${ }^{76}$.

W 1893 roku biskupi tarnowski, przemyski i lwowski w „Liście pasterskim” zakazali wiernym czytania pism ks. Stojałowskiego, grożąc nie subordynującym wiernym odmówieniem udzielania sakramentów. Już wcześniej z ich polecenia proboszczowie parafii ogłaszali w różnych pismach swoje protesty przeciwko ruchowi chłopskiemu kierowanemu przez ks. Stojałowskiego i czynili trudności w udzielaniu sakramentów czytelnikom jego pism ${ }^{77}$. W marcu 1895 roku ukazał się list pasterski biskupów: Morawieckiego, Łobosa, Soleckiego i Puzyny. Zarzucili mu wyszydzanie władzy świeckiej i duchownej oraz szerzenie nienawiści w społeczeństwie, co jest nie do pogodzenia z obowiązkami duszpasterza. Stojałowski listy biskupów komentował mówiąc, że nieomylny jest jedynie papież, a nie biskupi, zwłaszcza co do oceny jakiejś konkretnej osoby ${ }^{78}$.

$\mathrm{Na}$ początku XX wieku, gdy ordynariuszem diecezji przemyskiej był Józef Sebastian Pelczar, w diecezji nabrano bardzo stonowanego tonu w stosunku do działa ks. Stojałowskiego, podkreślając jego dobre chęci, jeśli chodzi o działalność oświatową i społeczną. W czasopiśmie „Echo Przemyskie" ukazał się tekst, w którym jako główną przyczynę kontrower-

75 J. Wołczański, dz. cyt., s. 394.

${ }^{76}$ Cyt. za: tamże, s. 391-392.

77 J. Zamorski, dz. cyt., s. 46.

78 B. Filarecka, dz. cyt., s. 39. 
sji wokół ks. Stojałowskiego wskazywano na to, że „szlachta nie stojąca na wyżynie swego powołania, nie była przygotowana do szybko po sobie następujących przeobrażeń"79. W diecezji przemyskiej życzliwie do ks. Stojałowskiego odnosił się sufragan Jakub Glazer ${ }^{80}$.

\section{OCENA OGÓLNA}

Sam ks. Stanisław Stojałowski uważał, że nie zachodzi sprzeczność pomiędzy jego działalnością a nauką Kościoła, a swoje wywody opierał na autorytecie nauczania papieży i wybitnych teologów. Pomimo powtarzających się zatargów z hierarchią Kościoła, zawsze był jej posłuszny ${ }^{81}$. Wychodził także z założenia, że decyzje władzy diecezjalnej w odniesieniu do jego działalności społeczno-politycznej nie są dla niego wiążące. Biskupi tymczasem żądali od niego posłuszeństwa także na tym polu, i w tym - zdaniem Daniela Olszewskiego - tkwiła przyczyna konfliktu ${ }^{82}$. Po usunięciu z probostwa wydał „List prywatny do braci kapłanów”, w którym pisał: ,jest to zupełnie z duchem Kościoła niezgodne pojęcie, bo władza jest tak długo władzą, póki sama przestrzega praw boskich i kościelnych... [...]. Żaden biskup nie ma prawa suspendować dla osobistej urazy i aby się upodobać świeckim! [...] Każdy (bowiem) rozkaz biskupa wtedy tylko w sumieniu jest ważny, gdy jest zgodny z prawem boskim i kościelnym [...]"83.

Zdaniem Kazimierza Turowskiego w stosunku do ks. Stojałowskiego biskupi popełnili wiele błędów, co było jedną z przyczyn upadku chrześcijańskiego ruchu ludowego, jednakże sam ks. Stojałowski często przekraczał dyscyplinę kościelną, potwierdzając to w swoim specjalnym oświadczeniu z 1897 roku po zdjęciu z niego klątwy przez Stolicę Apostolską ${ }^{84}$. W szelkie suspensy nakładane na ks. Stojałowskiego były odczy-

79 Tamże, s. 48.

80 Tamże, s. 38.

81 A. Kudłaszyk, Ksiądz Stanisław Stojałowski. Studium historyczno-prawne, Wrocław 1998, s. 15.

82 D. Olszewski, Szkice z dziejów kultury religijnej, Wrocław 1986, s. 11.

${ }^{83}$ Cyt. za: F. Kącki, dz. cyt., s. 155.

${ }^{84}$ K. Turowski, dz. cyt., s. 52. 
tywane oficjalnie we wszystkich kościołach znajdujących się na terenie Galicji $^{85}$. Na pewno wpływało to negatywnie na jego morale i w jakimś stopniu antagonizowało jego stosunki z wiernymi.

Ksiądz Stanisław Stojałowski był i pozostaje postacią kontrowersyjną, także jeśli chodzi o jego ocenę przez współczesnych historyków. Podczas gdy jedni podkreślają wkład duchownego w rozwój ruchu ludowego w Galicji, inni zarzucają mu zwyczajną demagogię zwodzącą tłumy ${ }^{86}$. Nie bez znaczenia były również jego cechy charakterologiczne. Józef Ryszard Szaflik, dokonując oceny działalności ks. Stojałowskiego, stwierdził, że przyczyną jego problemów i konfliktu $\mathrm{z}$ innymi duchownymi były cechy jego charakteru, takie jak „apodyktyczność, gwałtowność, autorytaryzm i nie liczenie się z innymi, i to zarówno przełożonymi, jak i przyjaciółmi oraz oddanymi mu zwolennikami i współpracownikami” ${ }^{87}$. Postawa Stojałowskiego była bardzo dotkliwa dla jego siostry Wandy, zakonnicy. Jej przyczynę upatrywała $\mathrm{w}$ wygórowanej ambicji i temperamencie brata. W listach prosiła go o ukorzenie się przed arcybiskupem; podobne prośby kierowali do niego inni krewni i znajomi z parafii Kulikowskiej. Wszystkie zignorowal ${ }^{88}$.

Ksiądz Aleksander Wóycicki, profesor socjologii chrześcijańskiej na KUL oraz na Uniwersytecie Stefana Batorego w Wilnie stwierdził, że ks. Stojałowski „krzywdę przyniósł raczej niż pożytek i ludowi polskiemu, i Kościołowi""s. Andrzej Kaleta, dokonując oceny jego postaci, konstatuje: „niezależnie od wszystkiego pozostawił po sobie wrażenie osoby barwnej, dynamicznej, o otwartym umyśle, zdolnym do sięgania po nowe idee i wprowadzania ich w życie przy wykorzystaniu nowoczesnych mediów, nawet jeśli wiązało się to z trudnościami i ograniczeniami”90.

85 Tamże.

86 A. Kaleta, dz. cyt., s. 133.

87 J. Szaflik, Ksiądz Stanisław Stojałowski - prekursor Ruchu Ludowego, w: Chłopi, naród, kultura, t. 2, Działalność polityczna ruchu ludowego, red. S. Dąbrowski, Rzeszów 1996, s. 176.

88 F. Kącki, dz. cyt., s. 134.

${ }^{89}$ K. Turowski, Historia ruchu chrześcijańsko-demokratycznego w Polsce, cz. 1, Warszawa 1989, s. 29.

90 Tamże. 
Podsumowując, należy stwierdzić, że pomimo usilnych starań nie udało się ks. Stojałowskiemu przekonać do swoich poglądów większości biskupów Kościoła katolickiego. Duchowni dostrzegali sprzeczność jego poglądów z nauką społeczną Kościoła; nie bez znaczenia był też wzrost nastrojów społecznych w Galicji, których się obawiano, a działalność wydawcy „Wieńca” i „Pszczółki” mogła te konflikty jeszcze bardziej zintensyfikować. Nie mniej jednak pozostawił on po sobie spuściznę, do której chętnie czasem powracano już wiele lat po jego śmierci, co stanowi obecnie przedmiot licznych badań. „Dorobek księdza, który szerzył na wsi postawy patriotyczne i obywatelskie oraz dbał o rozwój świadomości narodowej, stał się fundamentem dla wielu późniejszych działaczy stronnictw i organizacji chłopskich"91.

\section{BIBLIOGRAFIA}

\section{Źródła:}

Komar E., Kardynał Puzyna. Moje wspomnienia, Kraków 1912.

\section{Opracowania:}

Bieś A. P. SJ, Jan Badeni SJ (1858-1899). U początków ruchu społecznego katolików w Galicji, Kraków 2012.

Brodowska-Kubicz H., Świadomość społeczno-narodowa chłopów. U podstaw ruchu ludowego, w: Chłopi, naród, kultura, t. 2, Działalność polityczna ruchu ludowego, red. S. Dąbrowski, Rzeszów 1996.

Brodowska-Kubicz H., Świadomość społeczno-narodowa chłopów. U podstaw ruchu ludowego, w: Chłopi, naród, kultura, t. 2, Działalność polityczna ruchu ludowego, red. S. Dąbrowski, Rzeszów 1996.

Chrobak T., Etos chłopski w programach stronnictw ludowych, Rzeszów 1992.

Dunin-Wąsowicz K., Czasopiśmiennictwo ludowe w Galicji, Wrocław 1952.

Dunin-Wąsowicz K., Dzieje Stronnictwa Ludowego w Galicji, Warszawa 1956.

Dunin-Wąsowicz K., Ludowcy i socjaliści w Galicji, w: Chłopi, naród, kultura, t. 2, Działalność polityczna ruchu ludowego, red. S. Dąbrowski, Rzeszów 1996.

Filarecka B., Zarys stosunku Kościoła do ruchu ludowego w diecezji przemyskiej, „Premislia Christiana" 2001, t. IX.

Jakubiec P., „Dwie dusze” - czyli ewolucja tożsamości społecznej i narodowej ludności chłopskiej Galicji w drugiej połowie XIX i na początku XX wieku, „Zeszyty Naukowe Uniwersytetu Jagiellońskiego. Prace Historyczne” 2017, nr 144.

91 P. Jakubiec, dz. cyt., s. 420. 
Kaleta A., Stanowisko władz kościelnych wobec ruchu ludowego w Galicji na przykładzie społecznej i wydawniczej działalności księdza Stanisława Stojałowskiego, „Toruńskie Studia Bibliologiczne", 2013, nr 2 (11).

Kącki F., Ks. Stanisław Stojałowski i jego działalność społeczno-polityczna, Lwów 1937.

Kudłaszyk A, Ksiądz Stanisław Stojałowski. Studium historyczno-prawne, Wrocław 1998.

Olszewski D., Kościót katolicki a ruch ludowy na ziemiach polskich na przełomie XIX i XX wieku, w: Wieś polska wobec wyzwań, przełomów i zagrożeń (XIX i XX wiek), red. M. Przeniosło, S. Wiech, Kielce 2005.

Szaflik J., Ksiadz Stanisław Stojałowski - prekursor Ruchu Ludowego, w: Chłopi, naród, kultura, t. 2, Działalność polityczna ruchu ludowego, red. S. Dąbrowski, Rzeszów 1996.

Szymański Ł., Powstanie i rozwój ruchu ludowego w Galicji na przełomie XIX i XX wieku, „Acta Erasmiana” 2014, t. 6,

Turowski K., Historia ruchu chrześcijańsko-demokratycznego w Polsce, cz. 1, Warszawa 1989.

Wołczański J., Listy ks. Stanisława Stojałowskiego do arcybiskupa Józefa Bilczewskiego z lat 1901-1902, Nasza przeszłość, 1998, t. 90.

Zakrzewski A., Od Stojałowskiego do Witosa, Warszawa 1988.

Zamorski J., Ks. Stanisław Stojałowski, Bielsko 1931. 